\title{
CONVENTIONAL AND CONSTITUTIONAL REGULATIONS OF LAWFUL DETENTION OF A PERSON WITHOUT A COURT DECISION: CRIMINAL PROCEDURE ASPECT
}

\author{
Andrew Medvid, \\ Associate Professor of Department of theory of state and law, \\ Lviv University of trade and economics, \\ arbitrator of the Permanent arbitration court \\ at the Ukrainian chamber of commerce and industry, \\ Doctor of Juridical Science, Associate Professor, \\ https://orcid.org/0000-0001-9044-6505 \\ ResearcherID: G-2979-2019 \\ (https://publons.com/researcher/1766383/andrew-b-medvid/) \\ yurist.lpp@gmail.com
}

\section{Summary}

The article compares the requirements for the lawful application of detention without a court decision as a criminal procedure established in Article 5 \$ 1 (c) of the Convention for the Protection of Human Rights and Fundamental Freedoms and in the second sentence of Article 29 part 3 of the Constitution of Ukraine. In particular, the content of the concept of "detention" of a person is studied, the list of subjects who have the right to detain a person without a court decision and the legal content and list of legitimate grounds for detention of a person without a court decision as a criminal procedure are studied and compared. Conventional, constitutional and criminal-procedural norms are also studied, as well as the necessity of mandatory further judicial review of the legality of the detention of a person, including the terms of such review.

Based on a detailed analysis of these provisions of the Convention for the Protection of Human Rights and Fundamental Freedoms, the Constitution of Ukraine, relevant decisions of the European Court of Human Rights and the Criminal Procedure Code of Ukraine, it is established that the grounds for the detention of a person by a general entity, defined by paragraph 2 of Article 207 of the Criminal Procedure Code of Ukraine, and a special entity, defined by subparagraphs 1 and 2 (except subparagraph 3) of paragraph 1 of Article 208 of the Criminal Procedure Code of Ukraine, in general, correspond to the grounds for lawful detention of a person enshrined in Article $5 \S 1$ (c) of the Convention for the Protection of Human Rights and Fundamental Freedoms. Therefore, it cannot be qualified as unlawful interference with the human right to liberty and security of person. At the same time, proposals are formulated to make changes and additions to subparagraph 3 of paragraph 1 of Article 208 of the Criminal Procedure Code of Ukraine.

It is also proved that the provisions of paragraph 2 of Article 12 and Articles 209 and 211 of the Criminal Procedure Code of Ukraine are critical provisions of the current legislation of Ukraine regarding the lawful application of detention of a person without a court decision. These provisions actually eliminate some shortcomings and establish the necessary legal and procedural grounds for the clarified application of the provision of the second sentence of part 3 of Article 29 of the Constitution of Ukraine, in accordance with the provi- 
sions of paragraph 3 of Article 5 of the European Convention for the Protection of Human Rights and Fundamental Freedoms, as well as the practice of their application developed by the European Court of Human Rights.

Key words: detention of a person, subjects and grounds for lawful detention of a person without a court decision, right to liberty and security, Convention for the Protection of Human Rights and Fundamental Freedoms, Constitution of Ukraine, Criminal Procedure Code of Ukraine.

\section{Introduction}

Convention for the Protection of Human Rights and Fundamental Freedoms of 1950 (hereinafter - the Convention), which was ratified by the Verkhovna Rada of Ukraine in 1997 (Law of Ukraine "On Ratification of the Convention for the Protection of Human Rights and Fundamental Freedoms of 1950. First Protocol and Protocols, 2, 4, 7 and 11 of the Convention", 1997), in accordance with Article 9 of the Constitution of Ukraine (Constitution of Ukraine, 1996) is part of the national legislation of Ukraine and is subject to mandatory application in our country. At the same time, one of the most important fundamental and inalienable human rights is the right to liberty and security of person, which is guaranteed by Article 5 of the Convention and Article 29 of the Constitution of Ukraine. However, at present in the domestic legal system the issue of actual observance and proper protection of the human right to liberty and security of person, and in particular, ensuring the guarantee of exclusively lawful detention of a person without a court decision, remains a significant challenge.

It should be noted that the issue of effective protection of the right to liberty and security of person has been studied in the works of many scholars. For example, in the special literature consideration of the specified legal institute was carried out by such scientists and practitioners as: Y. Bisaga, N. Karpachova, M. Kozyubra, A. Kolodiy, M. Orzikh, V. Pogorilko, B. Poshva, P. Rabinovych, V. Tatsiy, Y. Todyka, O. Frytsky, V. Shapoval and others.

However, the problem of comparative study of the provisions of the Convention for the Protection of Human Rights and Fundamental Freedoms and the Constitution and the current Criminal Procedure Code of Ukraine on the range of subjects and grounds for lawful deten- tion without trial remains insufficiently investigated. That is why the study of this issue is determined by the purpose of this scientific article.

\section{Definition of «detention» of a person}

Examining the provisions of Part 3 of Article 29 of the Constitution of Ukraine, it should be noted that its second sentence only indirectly indicates the possibility of applying without a court decision such a measure as "detention" of a person and does not establish the grounds and procedure for its application. In particular, the second sentence of Part 3 of Article 29 of the Constitution of Ukraine states: "A detained person shall be released immediately if he is not served with a reasoned court decision on detention within seventy-two hours from the moment of detention» (Constitution of Ukraine, 1996).

In this regard, the Constitutional Court of Ukraine in paragraph 3.5. Decision № 10-rp / 2011 of 11 October 2011 states: "the analysis of the above constitutional provision shows that in this case it is a question of detention of a person as an exceptional temporary precautionary measure, the maximum duration of which should not exceed seventy-two hours without a reasoned court decision». In paragraph 3.4. of the same decision, the national body of constitutional jurisdiction states: "the words «detain», «hold» mean to leave, keep someone for some time in a certain place, position» (decision of the Constitutional Court of Ukraine № 10-rp / 2011 of 11 October 2011).

Therefore, in accordance with the legal position of the Constitutional Court of Ukraine set out in paragraph 6 of the judgment of 26 June 2003 № 12-rp / 2003: «detention should be understood both as a temporary precautionary criminal procedure and as an administrative procedure, the application of which restricts the 
right to liberty and personal integrity of the individual».

Analyzing the detention of a person as a measure that is applied without a court decision in the criminal procedure aspect, it is worth paying attention to the following.

According to the norms of the current Criminal Procedure Code of Ukraine (Criminal Procedure Code of Ukraine, 2012), detention is a measure that has a dual procedural purpose and purpose. Thus, Article 131 of the current Criminal Procedure Code of Ukraine defines the detention of a person as one of the «measures to ensure criminal proceedings» used to achieve the effectiveness of these proceedings, while paragraph 2 of Article 176 of this Code defines the detention of a person as a single «temporary measure» grounds and in the manner prescribed by this Code».

\section{Subjects and legal grounds for the application of detention of a person without a court decision}

Accordingly, paragraphs 2 and 3 of Article 207 of the Criminal Procedure Code of Ukraine indicate: "2. Everyone has the right to detain without the decision of the investigating judge, the court any person other than those referred to in Article 482 of this Code:

1) when committing or attempting to commit a criminal offense;

2) immediately after the commission of a criminal offense or during the continuous prosecution of a person suspected of its commission.

3. Everyone who is not an authorized official (a person who has the right to detain by law) and has detained the relevant person in the manner prescribed by part two of this article, must immediately deliver it to the authorized official or immediately notify the authorized official of detention and whereabouts of a person suspected of committing a criminal offense "(Criminal Procedure Code of Ukraine, 2012).

At the same time, paragraph 1 of Article 208 of the Code of Criminal Procedure of Ukraine states: "An authorized official has the right to detain a person suspected of committing a crime punishable by imprisonment without the decision of the investigating judge or court, only in the following cases:

1) if this person was caught during the commission of a crime or an attempt to commit it
2) if immediately after the commission of the crime an eyewitness, including the victim, or a set of obvious signs on the body, clothing or scene indicate that this person has just committed the crime

3) if there are reasonable grounds to believe that it is possible to escape in order to evade criminal responsibility of a person suspected of committing a serious or especially serious corruption crime, which is under the jurisdiction of the National Anti-Corruption Bureau of Ukraine» (Criminal Procedure Code of Ukraine, 2012). In addition, the specifics of detention of certain categories of persons are determined by Chapter 37 of the Criminal Procedure Code of Ukraine.

As you can see, in accordance with the above provisions of the Criminal Procedure Code of Ukraine, the right to detain a person without the decision of the investigating judge, the court is given not only a special entity - «authorized officials», but also a general entity - «everyone» (any person). At the same time, the general entity has an obligation to immediately deliver the detained person to an authorized official or to notify him of the detention and whereabouts of the suspect.

It should be noted that neither Article 5 § 1 of the Convention for the Protection of Human Rights and Fundamental Freedoms, in general, nor its $\S(c)$, in particular, contain any indication as to the extent to which persons may apply permissible measures of imprisonment. specified paragraph cases. In addition, it should be noted that the judgment of the European Court of Human Rights (hereinafter the ECtHR) of 7 January 2010 in paragraphs 319-321 of the judgment of the European Court of Human Rights in the Case of Rantsev v. Cyprus and Russia, states: «consent to the loss of a person's liberty through private individuals or in case of inability to resolve the situation». Whereas in paragraph 239 of the later judgment of 13 December 2012 in the Case of El Masri v. the former Yugoslav Republic of Macedonia, the Grand Chamber of the European Court of Human Rights emphasized: «the first sentence of Article $5 \S 1$ establishes a positive the obligation of the state not only to refrain from actively violating these rights, but also to take appropriate measures to ensure protection against unlawful interference with these rights by all persons within its jurisdiction». 
Given that the obligation of the state is to ensure protection not from any interference, but only from «illegal» interference with these rights of «all persons within its jurisdiction", it can be concluded that in the practice of the ECtHR There is no mandatory provision in the provisions of Article $5 \S 1$ of the Convention that any interference by individuals with the right to liberty of another person is, a priori, an unlawful violation of such a right. Therefore, we can assume that provided that the interference of individuals with the right to liberty of another person without a court decision is carried out in accordance with the procedure established by law and clearly meets the grounds for lawful detention of a person defined in Article 5 § 1 (c). Convention, such interference will be recognized as lawful.

This conclusion is further confirmed by the fact that in paragraph 1 of the «Rules on the Application of Detention, the Conditions in Which It Occurs and the Implementation of Safeguards against Abuse», provided by Recommendation REC (2006) 13 of the Committee of Ministers of the Council of Europe of 27 September 2006, which apply to all persons suspected of committing an offense - the "right of civil arrest" is given as an example of the application of the initial short deprivation of liberty «by anyone other authorized to apply such a measure», except the police or another law enforcement officer.

Guided by the above and in order to determine the legality of the grounds for detention without a court decision, both general and special entities defined in paragraph 2 of Article 207 and paragraph 1 of Article 208 of the Criminal Procedure Code of Ukraine, it is advisable to examine their compliance with the grounds for lawful detention. Article 5, paragraph 1, subparagraph (c), of the Convention for the Protection of Human Rights and Fundamental Freedoms.

Thus, the norms of the Criminal Procedure Code of Ukraine define quite similar lists of grounds for detention by both general and special entities, although, of course, the list of these grounds for the right to detain by special entities is somewhat broader. In particular, it can be argued that the grounds for detention of a person by a general entity provided for in subparagraph 1 of paragraph 2 of Article 207 of the Criminal Procedure Code of Ukraine and a special entity provided for in subparagraph 1 of paragraph 1 of Article 208 of this Code are generally almost identical. grounds for lawful arrest or detention of a person as "reasonably considered necessary to prevent the commission of an offense», which is enshrined in Article $5 \S 1$ (c) of the Convention.

In turn, examining the provision of subparagraph 2 of paragraph 2 of Article 207 of the Criminal Procedure Code of Ukraine, it is seen that it establishes the existence of two alternative circumstantial-temporal features, namely - «immediately after the commission of a criminal offense» and «during continuous prosecution of a suspect. its commission" for application by the general subject of detention of the person. These signs, in our opinion, can be defined as objective and reasonable grounds for a person's suspicion of committing a criminal offense. Similarly, it can be argued that the provision of subparagraph 2 of paragraph 1 of Article 208 of the Criminal Procedure Code of Ukraine contains several such alternative circumstantial features for use by a special subject of detention. In particular, it is: if «immediately after the crime» «eyewitness,... victim» or «a set of obvious signs on the body, clothing or scene» indicate that «this person has just committed a crime». These signs can undoubtedly be defined as objective and reasonable grounds for suspicion of the specified person in committing a crime. And although none of the provisions of the two provisions of the Criminal Procedure Code of Ukraine contains a direct (formal) indication of the suspicion of a criminal offense, or mandatory, in the sense of the Convention, signs of suspicion as its "reasonableness», but in our opinion, they, taken as a whole, are fully covered by such grounds for detention as set out in Article $5 \S 1$ (c) of the Convention as: «if there is a reasonable suspicion that he has committed an offense... or fled after it has been committed».

This allegation is further substantiated by the fact that, in accordance with paragraph 32 of the judgment of the European Court of Human Rights in the Case of Fox, Campbell and Hartley v. The United Kingdom: «A reasonable suspicion of a criminal offense presupposes the existence of facts or information objective observer that the person concerned could have committed the crime». At the same time, in our opinion, the 
alternative circumstantial-temporal features enshrined in subparagraph 2 of paragraph 2 of Article 207 of the Criminal Procedure Code of Ukraine and subparagraph 2 of paragraph 1 of Article 208 of this Code are, in their legal content, alternative circumstantial-temporal features, in their legal content, are precisely those that directly indicate the existence of «facts or information that could convince an objective observer that the person concerned could have committed a crime».

A slightly different conclusion can be reached by analyzing the provision of subparagraph 3 of paragraph 1 of Article 208 of the Criminal Procedure Code of Ukraine. Thus, its content shows that the basis for the use of special subjects of detention is not the validity of suspicion of committing a crime of appropriate severity, but only reasonable grounds to believe that the possible escape of the suspect. At the same time, the detained person did not attempt or actually escape. Therefore, in our opinion, due to the lack of instructions on the mandatory presence of a "reasonable» suspicion of a person committing a crime and the absence of the fact of escape or attempted escape of this person, it cannot be stated unequivocally that the grounds for detention are defined in subparagraph 31 of Article 208 of the Criminal Procedure Code of Ukraine corresponds to at least one of the grounds for detention of a person enshrined in Article $5 \S 1$ (c) of the Convention.

\section{The maximum permissible period and judicial control over the detention of a person without a court decision}

An equally important issue in the study of the criminal procedural aspect of such a measure as the detention of a person without a court decision is to determine the maximum period of its application and the need to establish mandatory judicial control over it. It should be noted that in this context, the prescription of the second sentence of Part 3 of Article 29 of the Constitution of Ukraine contains a rather interesting semantic construction. In particular, it shows that within seventy-two hours from the moment of detention, a person must either be released or be served with a reasoned court decision to detain him. Thus, in fact, a maximum period of seventy-two hours is established, during which a person may be detained without a court decision. At the same time, the analyzed constitutional provision does not contain an instruction to conduct a mandatory judicial review of the validity and legality of the very fact of detention. In addition, the provision of the second sentence of Part 3 of Article 29 of the Constitution of Ukraine does not establish the mandatory need to bring the detained person to court. Instead, it is mandatory only to serve the person with a reasoned court decision on his / her detention.

In this connection, it should be emphasized that the exercise of immediate and automatic judicial control over the detention of a person is determined by the European Court of Human Rights for the purposes of Article $5 \S 3$ of the Convention. At the same time, this provision of the Convention stipulates that such a judicial review procedure includes mandatory delivery of the detainee to court, and as a general rule, the delivery time should not exceed four days, and in the absence of special difficulties or exceptional circumstances preventing delivery. judge before, its term should not exceed three days.

At the same time, it should be noted that the European Court of Human Rights, in interpreting the provisions of Article $5 \S 3$ of the Convention, in its judgment of December 1979 in Case of Schisser v. Switzerland, stated in paragraph 31: "official to listen to the person who was delivered before making a decision». This legal position of the European Court of Human Rights is applied in a number of its later judgments (Guide on Article 5 of the European Convention on $\mathrm{Hu}-$ man Rights. 2016, p. 25), including paragraph 50 of the judgment of the Grand Chamber of the European Court of Human Rights in the already mentioned Case of Aquilina v. Malta (1999), as well as in paragraph 46 of the judgment in the Case of Kornev and Karpenko v. Ukraine (2011).

In view of this, there are sufficient grounds to state that the provision of the second sentence of part 3 of Article 29 of the Constitution of Ukraine only partially meets the requirements of paragraph 3 of Article 5 of the Convention. Thus, the maximum term established in this provision of the Constitution of Ukraine, lasting seventy-two hours, during which a person may be detained without a court decision, generally does not exceed the time limit for bringing a person to a judge (court) for judicial control 
over detention or arrest, applied in the case law of the European Court of Human Rights. However, the provision of the second sentence of Part 3 of Article 29 of the Constitution of Ukraine does not provide instructions on the mandatory judicial review of the validity and legality of the fact of detention, as well as the mandatory delivery of the detained person to court. And, this contradicts not only the provisions of paragraph 3 of Article 5 of the Convention, but also the main purpose of this provision, which is established and strictly observed in the case law of the European Court of Human Rights.

At the same time, it should be noted that the provision of the second sentence of Part 3 of Article 29 of the Constitution of Ukraine is developed in the norms of the Criminal Procedure Code of Ukraine. Thus, Article 12, paragraph 2, of the Code states: «Everyone who is detained on suspicion or accusation of committing a criminal offense or otherwise deprived of liberty must be brought before an investigating judge as soon as possible to decide on the lawfulness and justification of his detention, other deprivation of liberty and further detention. A detainee shall be released immediately if he or she has not been served with a reasoned detention order within seventy-two hours of his or her detention». Article 211 of the Criminal Procedure Code of Ukraine states: «The period of detention of a person without the decision of the investigating judge, court may not exceed seventy-two hours from the moment of detention, which is determined in accordance with Article 209 of this Code. A person detained without the decision of the investigating judge or the court must be released or brought to court no later than sixty hours from the moment of detention for consideration of a request to take a measure of restraint against him». In turn, Article 209 of the Criminal Procedure Code of Ukraine states: «A person is detained from the moment when he is forced to stay by force or through compliance with the order by an authorized official or in a room designated by an authorized official».

In our opinion, the above provisions of the Criminal Procedure Code of Ukraine are more in line with the provisions of paragraph 3 of Article 5 of the Convention and the case law of the European Court of Human Rights than the provision of the second sentence of part 3 of Article 29 of the Constitution. This is explained by the fact that, in contrast to the constitutional provision, the provisions of paragraph 2 of Article 12 of the Criminal Procedure Code of Ukraine investigating judge. This is explained by the fact that, unlike the constitutional provision, the provisions of paragraph 2 of Article 12 of the Criminal Procedure Code of Ukraine not only establish a total maximum of seventy-two hours during which a person may be detained without a court decision. They also establish the mandatory need to deliver the detainee to the investigating judge as soon as possible. Moreover, the provisions of Article 211 $\S 2$ of the Criminal Procedure Code of Ukraine set a maximum time limit for bringing a detainee to court, sixty hours from the moment of detention, stipulating that if they are violated, the detainee must be released. Thus, the provisions of Part 2 of Article 211 of the Criminal Procedure Code of Ukraine, as norms of a special domestic legislative act, divide the procedure of judicial control over the validity of detention and detention into two stages, namely: bringing a person to court and court proceedings as this is regulated by Article $5 \S 3$ of the Convention for the Protection of Human Rights and Fundamental Freedoms.

In addition, the provisions of Article 211 part 1 and Article 209 of the Criminal Procedure Code of Ukraine are fully consistent and even more specific than the provisions of the case law of the European Court of Human Rights on the interpretation of detention under Article $5 \S 3$ of the Convention. Thus, in a number of judgments, including paragraphs 23 and 24 in Case of Solmaz v. Turkey (2007), the ECtHR states: "In determining the period of detention pending trial, in accordance with Article 5 § 3 of the Convention, the period should be taken into account, starting on the day of the accused's detention and ending on the day of sentencing, even if it was passed only by the court of first instance». Whereas, the provision of Article 209 of the Criminal Procedure Code of Ukraine determines not the day of detention, but the moment of detention, which is extremely important given the need to establish the beginning of the seventy-two-hour period of detention.

\section{Conclusions}

Guided by the above, we conclude that in accordance with the provisions of the Criminal 
Procedure Code of Ukraine, detention is both a measure of criminal proceedings and the only temporary measure of restraint. At the same time, the right to detain a person without the decision of the investigating judge, the court is given not only a special entity - «authorized officials», but also a general entity - «everyone». In our opinion, the grounds for detention of a person by a general entity are defined in paragraph 2 of Article 207 of the Criminal Procedure Code of Ukraine and a special entity defined in subparagraphs 1 and 2 (except subparagraph 3) of paragraph 1 of Article 208 of the Criminal Procedure Code of Ukraine, in general , correspond to the grounds for the lawful detention of a person enshrined in Article 5 § 1 (c) of the Convention for the Protection of Human Rights and Fundamental Freedoms. In this regard, there are sufficient grounds to claim that the detention of a person without a court decision, based on the above provisions of the Criminal Procedure Code of Ukraine, is a lawful and lawful detention of a person in accordance with the provisions of the European Convention. human rights and therefore cannot be classified as unlawful interference with the human right to liberty and security of person guaranteed by Article 5 of the Convention.

At the same time, in order to ensure compliance with the provisions of $\S 1$ (c) of Article 5 of the Convention, the provisions of part 3 of paragraph 1 of Article 208 of the Criminal Procedure Code of Ukraine, it seems appropriate to amend this paragraph and state it as follows: «3) grounds to believe that it is possible to escape in order to evade criminal responsibility of a person in respect of whom there is a reasonable suspicion of committing a serious or especially serious corruption crime, referred by law to the jurisdiction of the National Anti-Corruption Bureau of Ukraine».

At the same time, it should be noted that the provisions of paragraph 2 of Article 12 and Articles 209 and 211 of the Criminal Procedure Code of Ukraine are critical and positive provisions of current legislation of Ukraine on the lawful application of detention without a court decision. The provisions of these articles of the Criminal Procedure Code of Ukraine actually eliminate certain shortcomings and establish the necessary legal and procedural grounds for clarified application of the provision of the second sentence of Part 3 of Article 29 of the Constitution of Ukraine, in accordance with Article $5 \S 3$ of the Convention for the Protection of Human Rights and Fundamental Freedoms and the case law of the European Court of Human Rights.

\section{Bibliography:}

1. Конвенція про захист прав людини і основоположних свобод (1950): Рада Європи. Офіційний вісник України 1998. № 13.

2. Конституція України (1996). Відомості Верховної Ради України. 1996. № 30. Ст.141. Спеціальний випуск. Ст. 15.

3. Кримінальний процесуальний кодекс України (2012): Кодекс України. Відомості Верховної Ради України. 2013. № 9, 10. Ст. 475.

4. Посібник зі статmі 5. Право на свободу та особисту недоторканність (2016). Рада Європи. Європейський суд 3 прав людини. 2016 р. URL: http://www.scourt. gov.ua/clients/vsu/vsu.nsf/7864c99c46598282c225 7b4c0037c014/04041cb11a2e814ec2257f99004119 06/\$FILE/\%D0\%9F\%D0\%BE\%D1\%81\%D1\%96\%D0\% B1\%D0\%BD\%D0\%B8\%D0\%BA_\%D1\%81\%D1\%82_5_ \%D0\%9F\%D1\%80\%D0\%B0\%D0\%B2\%D0\%BE_\%D0\% BD\%D0\%B0_\%D1\%81\%D0\%B2\%D0\%BE\%D0\%B1\%D 0\%BE\%D0\%B4\%D1\%83.pdf

5. Правила застосування тримання під вартою, умов, у яких воно відбувається, і запровадження гарантій від зловживань (2006): Рекомендація REC (2006) 13 Комітету Міністрів Ради Європи державам-учасницям. URL: https://rm.coe.int/16806f40e5

6. Про ратифікацію Конвенції про захист прав і основних свобод людини 1950 року. Першого протоколу та протоколів № 2, 4, 7 та 11 до Конвенції (1997): Закон України № 475/97-ВР. Голос України. 1997.

7. Рішення Конституційного Суду України у справі за конституційним поданням 50 народних депутатів України щодо відповідності Конституції України (конституиійності) окремих положень статті 263 Кодексу України про адміністративні правопорушення та пункту 5 частини першої статті 11 Закону України «Про міліцію» (справа про строки адміністративного затримання) (2011). № 10-рп/2011. Вісник Конституційного суду України 2011 р. № 6. Ст. 121.

8. Рішення Конституційного Суду України у справі за конституційним поданням 56 народних депутатів україни про офіційне тлумачення положень частин першої, третьої статті 80 Конституиії України, частини першої статті 26, частин першої, другої, 
третьої статті 27 Закону України «Про статус народного депутата України» та за конституційним поданням Міністерства внутрішніх справ України про офіиійне тлумачення положення частини третьої статті 80 Конституиії України стосовно затримання народного депутата України (справа про гарантії депутатської недоторканності) (2003) № 12-рп/2003. Офіційний вісник України 2003 р. № 28. Ст. 119.

9. Case of Kornev and Karpenko v. Ukraine. Application no. 17444/04. Judgment Strasbourg 21 October 2010. The European Court of Human Rights. URL: https://www. hr-dp.org/files/2013/09/07/CASE_OF_KORNEV_AND_ KARPENKO _v._UKRAINE_.pdf

10. Case of Aquilina v. Malta. Application no. 25642/94. Grand Chamber. Judgment Strasbourg 29 April 1999. The European Court of Human Rights. URL: https:// hudoc.echr.coe.int/eng\# [“itemid”:[“001-58239”]\}

11. Case of El-Masri v. the former Yugoslav Republic of Macedonia. Application no. 39630/09. Grand Chamber. Judgment Strasbourg 13 December 2012. URL: http:// hudoc.echr.coe.int/eng?i=001-115621

12. Case of Fox, Campbell and Hartley v. the United Kingdom. Application no. 12244/86; 12245/86; 12383/86. Judgment Strasbourg 30 August 1990. The European Court of Human Rights. URL: http://hudoc.echr.coe.int/ eng? $\mathrm{i}=001-57721$

13. Case of Rantsev v. Cyprus and Russia. Application no. 25965/04. Judgment Strasbourg 7 January 2010. The European Court of Human Rights. URL: http://hudoc. echr.coe.int/eng?i=001-96549

14. Case of Schiesser v. Switzerland. Application no. 31195/96. Judgment Strasbourg 25 March 1999. The European Court of Human Rights. URL: https://hudoc. echr.coe.int/eng\#\{«itemid»:[«001-58228»]\}

15. Case of Solmaz v. Turkey. Application no. 27561/02. Judgment Strasbourg 16 January 2007. The European Court of Human Rights. URL: http://hudoc.echr.coe.int/ eng? $i=001-79053$

\section{References:}

1. Konventsiia pro zakhyst prav liudyny i osnovopolozhnykh svobod. Rada Yevropy [Convention for the Protection of Human Rights and Fundamental Freedoms] (1950). Ofitsijnyj visnyk Ukrainy.1998 . № 13, № 32. [in Ukrainian].

2 Konstytutsiia Ukrainy [The Constitution of Ukraine] (1996). Vidomosti Verkhovnoi Rady Ukrainy. 1996. № 30. St.141. № 72/1 Spetsial'nyj vypusk, P. 15. [in Ukrainian].

3. Kry'minal'ny j̈ procesual 'ny"j kodeks Ukrayiny' [Criminal Procedure Code of Ukraine] (2012). Zakon vid
13.04.2012, № 4651-VI. Vidomosti Verxovnoyi Rady Ukrayiny. 2013. № 9-10 [in Ukrainian].

4. Posibny'k zi statti 5. Pravo na svobodu ta osoby'stu nedotorkannist'[Guide on Article 5of the European Convention on Human Rights. Right to liberty and security] (2016), Rada Yevropy. Yevropejs`ky j sud z prav lyudy`ny`. 2016 r. Available from: http://www.scourt. gov.ua/clients/vsu/vsu.nsf/7864c99c46598282c225 7b4c0037c014/04041cb11a2e814ec2257f99004119 06/\$FILE/\%D0\%9F\%D0\%BE\%D1\%81\%D1\%96\%D0\% B1\%D0\%BD\%D0\%B8\%D0\%BA_\%D1\%81\%D1\%82_5_ \%D0\%9F\%D1\%80\%D0\%B0\%D0\%B2\%D0\%BE_\%D0\% BD\%D0\%B0_\%D1\%81\%D0\%B2\%D0\%BE\%D0\%B1\%D 0\%BE\%D0\%B4\%D1\%83.pdf. [in Ukrainian].

5. Pravy'la zastosuvannya try'mannya pid vartoyu, umov, u yaky'x vono vidbuvayet'sya, i zaprovadzhennya garantij vid zlovzhy van'[On the use of remand in custody, the conditions in which it takes place and the provision of safeguards against abuse] (2006), Rekomendaciya REC (2006) 13 Komitetu Ministriv Rady ' Yevropy` derzhavamuchasny`cyam vid 27 veresnya 2006 r. Available from: https://rm.coe.int/16806f40e5. [in Ukrainian].

6. Pro ratyfikatsiiu Konventsii pro zakhyst prav i osnovnykh svobod liudyny 1950 roku. Pershoho protokolu ta protokoliv № 2, 4, 7 ta 11 do Konventsii [On ratification of the Convention for the Protection of Human Rights and Fundamental Freedoms of 1950. First Protocol and Protocols № 2, 4, 7 and 11 to the Convention] (1997), Zakon Ukrainy № 475/97-VR. Holos Ukrainy.1997.[in Ukrainian].

7. Rishennya Konsty tucijnogo Sudu Ukrayiny' u spravi za konsty'tucijny'm podannyam 50 narodny'x deputativ Ukrayiny' shhodo vidpovidnosti Konsty'tuciyi Ukrayiny' (konsty 'tucijnosti) okremy’x polozhen 'statti 263 Kodeksu Ukrayiny' pro administraty'vni pravoporushennya ta punktu 5 chasty 'ny pershoyi statti 11 Zakonu Ukrayiny' «Pro miliciyu» (sprava pro stroky` administraty vnogo zatry'mannya) [Decision of the Constitutional Court of Ukraine in the case on the constitutional petition of 50 deputies of Ukraine on compliance with the Constitution of Ukraine (constitutionality) of certain provisions of Article 263 of the Code of Administrative Offenses and paragraph 5 of part 1 of Article 11 of the Law of Ukraine "On Police"] (2011). № 10-rp/2011. Visny`k Konsty`tucijnogo sudu Ukrayiny`. 2011. № 6. P. 121. [in Ukrainian].

8. Rishennya Konsty 'tucijnogo Sudu Ukrayiny' u spravi za konsty'tucijny'm podannyam 56 narodny'x deputativ Ukrayiny 'pro oficijne tlumachennya polozhen 'chasty'n pershoyi, tret'oyi statti 80 Konsty'tuciyi Ukrayiny; chasty 'ny' pershoyi statti 26, chasty'n pershoyi, drugoyi, tret 'oyi statti 27 Zakonu Ukrayiny " Pro status narodnogo 
deputata Ukrayiny'» ta za konsty'tucijny'm podannyam Ministerstva vnutrishnix sprav Ukrayiny' pro oficijne tlumachennya polozhennya chasty 'ny' tret'oyi statti 80 Konsty 'tuciyi Ukrayiny 'stosovno zatry 'mannya narodnogo deputata Ukrayiny' (sprava pro garantiyi deputats koyi nedotorkannosti) [Decision of the Constitutional Court of Ukraine in the case on the constitutional petition of 56 people's deputies of Ukraine on official interpretation of the provisions of parts one, three of Article 80 of the Constitution of Ukraine, part one of Article 26, parts one, two, three of Article 27 of the Law of Ukraine "On Status of People's Deputy of Ukraine" and on the constitutional petition of the Ministry of Internal Affairs of Ukraine on the official interpretation of the provision of part three of Article 80 of the Constitution of Ukraine concerning the detention of a People's Deputy of Ukraine (case on guarantees of parliamentary immunity)] (2003) № 12rp/2003. Oficijny`j visny`k Ukrayiny`. 2003. № 28. [in Ukrainian].

9. Case of Kornev and Karpenko v. Ukraine. Application no. 17444/04. Judgment Strasbourg 21 October 2010. The European Court of Human Rights. URL: https://www. hr-dp.org/files/2013/09/07/CASE_OF_KORNEV_AND_ KARPENKO_v._UKRAINE_.pdf
10. Case of Aquilina v. Malta. Application no. 25642/94. Grand Chamber. Judgment Strasbourg 29 April 1999. The European Court of Human Rights. URL: https:// hudoc.echr.coe.int/eng\#\{«itemid»:[«001-58239»]\}

11. Case of El-Masri v. the former Yugoslav Republic of Macedonia. Application no. 39630/09. Grand Chamber. Judgment Strasbourg 13 December 2012. URL: http:// hudoc.echr.coe.int/eng?i=001-115621

12. Case of Fox, Campbell and Hartley v. the United Kingdom. Application no.12244/86; 12245/86; 12383/86.Judgment Strasbourg 30 August 1990. The European Court of Human Rights. URL: http://hudoc.echr.coe.int/eng?i=001-57721

13. Case of Rantsev v. Cyprus and Russia. Application no. 25965/04. Judgment Strasbourg 7 January 2010. The European Court of Human Rights. URL: http://hudoc. echr.coe.int/eng?i=001-96549

14. Case of Schiesser v. Switzerland. Application no. 31195/96. Judgment Strasbourg 25 March 1999. The European Court of Human Rights. URL: https://hudoc. echr.coe.int/eng\#\{«itemid»:[«001-58228»]\}

15. Case of Solmaz v. Turkey. Application no. 27561/02. Judgment Strasbourg 16 January 2007. The European Court of Human Rights. URL: http://hudoc.echr.coe.int/ eng?i=001-79053

\title{
КОНВЕНЦІЙНА ТА КОНСТИТУЦІЙНА РЕГЛАМЕНТАЦІЯ ПРАВОМІРНОГО ЗАТРИМАННЯ ОСОБИ БЕЗ РІШЕННЯ СУДУ: КРИМІНАЛЬНО-ПРОЦЕСУАЛЬНИЙ АСПЕКТ
}

\author{
Андрій Медвідь, \\ доцент кафедри теорії держави і права, \\ Львівський торговельно-економічний університет, \\ третейський суддя Постійно діючого третейського суду при \\ Торгово-промисловій палаті України, \\ доктор юридичних наук, доцент, \\ https://orcid.org/0000-0001-9044-6505
}

ResearcherID: G-2979-2019 (https://publons.com/researcher/1766383/andrew-b-medvid/) yurist.lpp@gmail.com

\section{Анотація}

У статті здійснюється компаративістьке дослідження вимог щодо правомірного застосування затримання особи без рішення суду, як кримінально-процесуального заходу, які встановлені у підпункті «с)» пункту 1 статті 5 Конвениії про захист прав людини і основоположних свобод та у другому реченні частини 3 статті 29 Конституції України. Зокрема, досліджується зміст поняття «затримання» особи, вивчається та порівнюється перелік суб'єктів, які наділені правом затримувати особу без рішення суду та юридичний зміст $і$ 
перелік правомірних підстав затримання особи без рішення суду, як кримінально-процесуального заходу. Також досліджуються конвенційні, конституційні та кримінально-процесуальні норми, що необхідності обов'язкового проведення подальшої судової перевірки правомірності застосування затримання особи, включно із строками проведення такої перевірки.

На основі детального аналізу вказаних положень Конвенції про захист прав людини і основоположних свобод, Конституції України, відповідних рішень Європейського суду з прав людини та Кримінального процесуального кодексу України встановлюється що підстави для застосування затримання особи загальним субєктом, визначені пунктом 2 статті 207 Кримінального процесуального кодексу України, та спеціальним суб'єктом, визначені підпунктами 1 та 2 (за винятком підпункту 3) пункту 1 статті 208 Кримінального процесуального кодексу України, загалом, відповідають підставам застосування правомірного затримання особи закріпленим у підпункті «с)» пункту 1 статті 5 Конвенції про захист прав людини і основоположних свобод, а отже не може кваліфікуватися як незаконне втручання в право людини на свободу та особисту недоторканність. Водночас, формулюються пропозиції щодо внесення змін та доповнень до підпункту 3 пункту 1 статті 208 Кримінального процесуального кодексу України.

Також обгрунтовується, що положення пункту 2 статті 12 та статей 209 і 211 Кримінального процесуального кодексу України є критично важливими положеннями чинного законодавства України, щодо правомірного застосування затримання особи без рішення суду. Вказані положення фактично усувають окремі недоліки та встановлюють необхідні юридично-процесуальні підстави для уточненого застосування припису другого речення частини 3 статті 29 Конституції України, відповідно до вимог положень пункту 3 статті 5 Європейської конвенції про захист прав людини і основоположних свобод, а також практики ї застосування напрацьованої Європейським судом з прав людини.

Ключові слова: затримання особи, субєєкти та підстави правомірного затримання особи без рішення суду, право на свободу та особисту недоторканність, Конвенція про захист прав людини і основоположних свобод, Конституція України, Кримінальний процесуальний кодекс України. 